\title{
PERILAKU FRAUD MAHASISWA DAN PERSEPSINYA TERHADAP ASPEK - ASPEK UMUM ETIKA BISNIS DAN TUJUAN PENDIDIKAN ETIKA PROFESI AKUNTANSI DITINJAU DARI JENIS KELAMIN
}

\author{
Annisa Asriati $^{1)}$, Hajan Hidayat ${ }^{2)}$ \\ Jurusan Akuntansi Manajerial, Politeknik Negeri Batam \\ Jl. Ahmad Yani, Batam Centre, Batam 29461, Indonesia \\ 1) E-mail: annisa.asriati04@gmail.com \\ ${ }^{2)}$ E-mail: hajan@polibatam.ac.id
}

\begin{abstract}
Abstrak
Mahasiswa dibekali dengan pendidikan etika bisnis dengan harapan mahasiswa akan menjadi seorang akuntan yang baik tanpa melanggar etika dan bekerja secara profesional. Penelitian ini bertujuan untuk mengetahui bagaimana persepsi mahasiswa berdasarkan jenis kelamin terhadap aspek-aspek umum etika bisnis, tujuan pendidikan etika profesi akuntansi dan bagaimanakah perilaku mahasiswa berdasarkan jenis-jenis fraud. Sampel pada penelitian ini adalah 499 mahasiswa kelas malam progam studi akuntansi di universitas terakreditasi baik di Kota Batam. Pengujian hipotesis dalam penelitian ini menggunakan alat uji mann withney $u$ test dan statistik deskriptif yang terdapat pada SPSS 17.00. Hasil menunjukkan bahwa terdapat perbedaan persepsi antara mahasiswa laki-laki dan perempuan terhadap aspek-aspek umum etika bisnis dan tujuan pendidikan etika profesi akuntansi. Sebagian besar mahasiswa menganggap hal tersebut adalah penting namun sebagian besar mahasiswa mengakui pernah melakukan kecurangan berdasarkan jenis-jenis fraud internal. Mahasiswa yang bekerja di bank, mahasiswa semester 1 dan semester 3, mahasiswa yang sudah mendapatkan mata kuliah etika bisnis dan mahasiswa laki-laki mendominasi dalam kategori fraud. Keterbatasan dalam penelitian ini adalah sampel yang digunakan hanya mahasiswa program studi akuntansi kelas malam di Kota Batam. Pemberian ilmu lebih mendalam seputar etika bisnis dan juga pembelajaran tentang etika adalah perlu. Saran untuk penelitian selanjutnya adalah sampel yang diteliti di perluas, bisa menambahkan faktor eksternal yang menentukan perilaku kecurangan dan melakukan penelitian seputar kecurangan yang telah terjadi.
\end{abstract}

Kata Kunci: aspek-aspek umum etika bisnis, tujuan pendidikan etika profesi akuntansi, fraud internal, persepsi dan jenis kelamin

\footnotetext{
Abstract

Students reached education ethics business with hope students will become an accountant without breaking ethics and work professionally. This study aims to see how perception students on the basis of gender to general aspects of business ethics, importance of the objectives of accounting ethics education and how do behavior students based on the types of fraud. The sample in this research is 499 students of the night class of accounting study program at an accredited university in Batam City. Testing the hypothesis in this study using a mann withney u test and
} 
descriptive statistics in SPSS 17.00. The results show that there are differences in perception between male students and female students of general aspects of business ethics and importance of the objectives of accounting ethics education. Most students considered it is important but most students has admitted that they have commits fraud based on the type of fraud internal. A student who work in the bank, student semester 1 and semester 3, Students who have received lecture business ethics and student man Dominated in the category of fraud. Limitations of this study is sample use only students of the night class of accounting study program in Batam alone. The provision of the science more in-depth about ethics business and also study of ethics are need to. Suggestions for further research is sample examined across extend, can add external factors that determines fraud behavior and for research on fraud that has happened.

Key Words: General Aspects of Business Ethics, Importance of the Objectives of Accounting Ethics Education,Internal Fraud, Perception and Gender

\section{Pendahuluan}

Perkembangan dunia bisnis akan menimbulkan persaingan antara para pelaku bisnis seperti perusahaan. Pelaku bisnis tersebut pada umumnya memiliki tujuan untuk memperoleh keuntungan yang besar demi kesejahteraan dan memperluas jaringan usahanya. Terkadang dalam meraih keuntungan besar tersebut para pelaku bisnis mengambil jalan pintas dengan melakukan tindakan-tindakan yang mengabaikan moral dan etika dari bisnis (Poniman, 2009). Menurut ACFE (Association of Certified Fraud Examiners) menyebutkan terdapat kecurangan internal di dalam perusahaan terutama bagi profesi akuntan seperti korupsi, kolusi, nepotisme dan lain-lain. Salah satu usaha untuk mengurangi kecurangan tersebut adalah dengan pendidikan etika yang diberikan kepada mahasiswa ketika berada di bangku kuliah. Tanpa etika, profesi akuntan tidak berfungsi karena fungsi akuntan adalah penyedia informasi untuk proses pembuatan keputusan bisnis oleh para pelaku bisnis (Haspari, 2013). Diharapkan dengan pembekalan pendidikan etika tersebut mahasiswa akan menjadi seorang akuntan yang baik tanpa melanggar etika dan bekerja secara profesional. Mahasiswa merupakan salah satu pelaku bisnis di masa yang akan datang, terutama mahasiswa jurusan akuntansi. Mengetahui persepsi mahasiswa tentang aspek-aspek umum etika bisnis dan pentingnya tujuan pendidikan etika profesi akuntan adalah penting (Tormo, 2016). Hal tersebut sebagai gambaran pentingnya pendidikan etika di perguruan tinggi untuk menjadikan pelaku bisnis yang baik di masa yang akan datang. Undang-Undang Republik Indonesia No 2 Tahun 1986 tentang Sistem Pendidikan Nasional Bab 2 Pasal 4 menyatakan pendidikan pada dasarnya bertujuan untuk berbudi pekerti luhur, memiliki pengetahuan dan keterampilan, memiliki kepribadian yang mantap dan mandiri, dan memiliki rasa tanggung jawab kemasyarakatan dan kebangsaan. Maka dari itu pendidikan sangatlah penting terutama pendidikan etika profesi akuntan bagi para mahasiswa calon akuntan di masa depan. Tujuan dari penelitian ini adalah untuk memberikan bukti empiris mengenai persepsi mahasiswa berdasarkan jenis kelamin terhadap aspek-aspek umum etika bisnis, persepsi mahasiswa berdasarkan jenis kelamin terhadap tujuan pendidikan etika profesi akuntansi dan untuk mengetahui perilaku mahasiswa berdasarkan jenis-jenis fraud.

\section{Landasan Teori}

\section{Teori Tindakan Beralasan}

Teori tindakan beralasan (Theory of Reasoned Action) menghubungkan keyakinan (bealief), sikap (attitude), niat (intention) dan perilaku (behavior). Niat merupakan prediktor terbaik perilaku yaitu jika ingin mengetahui apa yang akan dilakukan seseorang cara terbaik untuk mengetahuinya adalah dengan mengetahui niat orang tersebut (Fishbein dan Ajzen, 1975). Theory of Reasoned Action (TRA) dikembangkan dan dimodifikasi oleh Ajzen (1985) dalam Theory of Planned Behavior (TPB). Theory of 
Planned Behavior (TPB) mencakup tiga hal penting. Pertama, keyakinan perilaku (behavioral beliefs) merupakan keyakinan tentang kemungkinan hasil dan evaluasi dari perilaku. Kedua, keyakinan normatif (normative beliefs) merupakan keyakinan tentang norma yang diharapkan dan motivasi untuk memenuhi harapan. Ketiga, keyakinan kontrol (control beliefs) merupakan keyakinan tentang adanya faktor yang dapat mendukung atau menghalangi perilaku dan kesadaran akan kekuatan faktor tersebut. Tahap selanjutnya adalah niat kemudian perilaku. Niat merupakan kecenderungan seseorang untuk memilih melakukan atau tidak melakukan suatu perilaku. Theory of Planned Behavior didasarkan pada asumsi bahwa manusia adalah makhluk yang rasional dan menggunakan informasi-informasi yang mungkin baginya (tersedia), secara sistematis.

\section{Etika}

Menurut Velasquez (2005) etika merupakan proses pemeriksaan standar moral orang atau masyarakat untuk menentukan apakah standar tersebut masuk akal atau tidak untuk diterapkan dalam situasi dan permasalahan konkret. Tujuan akhir standar moral adalah mengembangkan suatu standar moral yang kita rasa masuk akal untuk dianut. Etika dapat diterangkan sebagai sistem keyakinan mendukung sebuah bentuk fakta moralitas (Stedham et al., 2007). Salah satu yang paling klasik digunakan, diusulkan oleh Rest (1968), termasuk sebuah model bertingkat yang disusun oleh empat elemen. Pertama, kesadaran moral yaitu orang tersebut mampu mengidentifikasi aksi alternatif dan bagaimana alternatif tersebut mempengaruhi kesejahteraan pihak yang berkepentingan. Kedua, penilaian moral yaitu orang tersebut mampu menilai aksi mana yang seharusnya dilakukan dalam sebuah kondisi karena aksi tersebut secara moral benar. Ketiga, tujuan moral yaitu orang tersebut harus berniat untuk melakukan apa yang secara moral baik dengan memberikan prioritas pada nilai-nilai moral di atas nilai-nilai pribadinya sendiri. Keempat, perilaku yaitu orang tersebut harus memiliki ketekunan, kekuatan ego, dan implementasi keterampilan yang sanggup dilakukan melalui niat yang dimilikinya untuk berperilaku etis.

\section{Etika Bisnis}

Cara masyarakat dalam memandang dunia bisnis akan mempengaruhi pada praktik bisnis itu sendiri. Skandal bisnis yang menyangkut persaingan yang tidak sehat, pencucian uang, manipulasi pembukuan, penggelapan pajak, penipuan sekuritas dan lain-lain sungguh memprihatinkan dan harus segera diakhiri (Rinjani, 2004). Di Indonesia sendiri, korupsi tidak hanya dilakukan oleh pejabat pemerintah, tetapi juga oleh pelaku bisnis. Etika binis diperlukan untuk meningkatkan kualitas etika proses pembuatan keputusan dalam semua lini bisnis. Informasi menurut Adkins dan Radtke (2004) tentang empat area digunakan untuk menilai seberapa penting peranan etika bisnis yaitu:

1. Lingkungan bisnis

2. Mata kuliah etika bisnis

3. Pengambilan keputusan secara individu

4. pengambilan keputusan dalam pekerjaan

\section{Pendidikan Etika Profesi Akuntansi}

Pendidikan etika profesi akuntan pada tingkat yang minimal adalah dengan memperkenalkan mahasiswa khususnya mahasiswa program studi akuntansi sebagai calon akuntan dengan kode etik yang mengatur perilaku akuntan (Rustiana, 2006). Tujuan diberikan pendidikan etika profesi akuntansi kepada mahasiswa program studi akuntansi adalah (Callahan, 1980):

1. Menghubungkan pendidikan akuntansi kepada persoalan-persoalan moral

2. Mengenalkan persoalan-persoalan moral dalam akuntansi yang memiliki implikasi etis

3. Mengembangkan suatu perasaan bertanggung jawab moral

4. Mengembangkan kemampuan yang dibutuhkan dalam menghadapi konflik atau dilema etis

5. Belajar menghadapi ketidakpastian dalam profesi akuntansi

6. Sebagai tahapan untuk mencapai suatu perubahan dalam perilaku etis

7. Mengapresiasikan dan memahami sejarah dan komposisi seluruh aspek etika profesi akuntan dan hubungannya terhadap etika secara umum. 


\section{Persepsi}

Walgito (1989) mengemukakan ada tiga syarat untuk terjadinya persepsi yaitu: adanya objek yang dipersepsi, adanya alat indra atau reseptor dan adanya perhatian. Menurut Walgito (1989), terdapat tahaptahap dalam pembentukan persepsi dalam diri manusia. Pertama proses kealaman (fisik) yaitu berawal dari objek yang ada dan menimbulkan rangsangan kemudian rangsangan tersebut mengenai reseptor atau alat indera. Kedua proses fisiologis dimana rangsangan dari proses pertama diterima oleh alat indera kemudian dilanjutkan oleh saraf sensoris ke otak. Ketiga proses psikologis yaitu tahap proses di otak, sehingga manusia dapat menyadari apa yang ia terima sebagai suatu rangsangan yang diterimanya.

\section{Gender}

Eagly (1987) mengemukakan teori peran sosial didefinisikan dengan perbedaan dan persamaan jenis kelamin yaitu laki-laki dan perempuan dalam perilaku sosial. Menurut teori peran sosial yang dikemukakan oleh Eagly (1987), perbedaan perilaku perempuan dan laki-laki terjadi karena dua jenis kelamin itu menempati peran sosial yang berbeda dalam kehidupan sehariharinya. Orang biasanya menyesuaikan diri dengan keadaan dan norma yang diasosiasikan dengan peran spesifik dan berperilaku yang tepat secara sosial. Perbedaan peran tersebut menyebabkan laki-laki dan perempuan memiliki minat berbeda dan mengembangkan keterampilan yang berbeda.

Menurut Bem (1981) menyatakan gender merupakan karakteristik kepribadian yang dipengaruhi oleh peran gender yang dimiliki oleh masing-masing orang, peran gender tersebut dikelompokkan menjadi 4 diantaranya maskulin, feminine, androgini dan tak terbedakan. Maskulin adalah sifat-sifat yang dipercaya dan dibentuk oleh budaya sebagai ciri-ciri yang ideal bagi laki-laki (Nauly, 2002). Misalnya asertif dan dominan dianggap sebagai trait maskulin. Feminin merupakan ciri-ciri atau sifat-sifat yang dipercaya dan dibentuk oleh budaya sebagai ideal bagi wanita (Nauly, 2002). Misalnya penurut, ceria, pemalu dan lain-lain.

\section{Jenis-Jenis Fraud}

ACFE (Association of Certified Fraud Examiners) mengembangkan penipuan kerja dan sistem klasifikasi penyalahgunaan yang dikenal sebagai pohon kecurangan internal diantaranya:

1. Fraud Terhadap Aset (Asset Misappropriation)

Fraud terhadap aset merupakan penyalahgunaan aset perusahaan, baik yang dicuri atau digunakan untuk keperluan pribadi tanpa ijin dari perusahaan. Asset misappropriation dikelompokan menjadi 2, diantaranya cash misappropriation yang merupakan penyelewengan terhadap aset yang berupa kas dan non

cash misappropriation yang merupakan penyelewengan terhadap aset yang berupa non kas.

2. Fraud Terhadap Laporan Keuangan (Fraudulent Statements)

ACFE membagi jenis fraud terhadap laporan keuangan menjadi 2, diantaranya financial dan non financial.

3. Korupsi (Corruption)

ACFE membagi jenis tindakan korupsi menjadi 2, pertama konflik kepentingan (conflict of interest) seperti kolusi dan nepotisme, kedua menyuap atau menerima suap, imbal balik (briberies and excoriation).

\section{Hipotesis}

Penelitian Haspari (2013) menyimpulkan bahwa terdapat perbedaan yang signifikan tentang etika bisnis antara mahasiswa dan mahasiswi. Stedham et al (2007) menunjukkan bahwa terdapat perbedaan yang signifikan dalam etika bisnis yaitu niat untuk berperilaku antara laki-laki dan perempuan dan terdapat perbedaan yang signifikan tentang perspektif keadilan dalam etika bisnis antara laki-laki dan perempuan. Tormo (2016) menyimpulkan bahwa perempuan menganggap aspek umum etika lebih penting dari pada laki-laki. Menurut teori peran sosial yang dikemukakan oleh Eagly (1987), perbedaan perilaku perempuan dan laki-laki terjadi karena dua jenis kelamin itu menempati peran sosial yang berbeda dalam kehidupan sehari-harinya. Perbedaan peran tersebut menyebabkan perempuan dan laki-laki memiliki minat berbeda dan mengembangkan keterampilan yang berbeda (Taylor, 2009). Diperkirakan adanya perbedaan persepsi antara 
mahasiswa laki-laki dan mahasiswa perempuan sehingga hipotesis 1 dalam penelitian ini adalah: H1: Terdapat perbedaan persepsi antara laki-laki dan perempuan terhadap aspek-aspek umum etika bisnis. Penelitian Haspari (2013) menyimpulkan bahwa terdapat perbedaan yang signifikan tentang etika profesi antara mahasiswa dan mahasiswi. Tormo (2016) menyimpulkan bahwa perempuan menganggap tujuan pendidikan etika profesi akuntan lebih penting dari pada laki-laki. Menurut teori peran sosial yang dikemukakan oleh Eagly (1987), perbedaan perilaku perempuan dan laki-laki terjadi karena dua jenis kelamin itu menempati peran sosial yang berbeda dalam kehidupan sehari-harinya. Perbedaan peran tersebut menyebabkan perempuan dan laki-laki memiliki minat berbeda dan mengembangkan keterampilan yang berbeda (Taylor, 2009).

Diperkirakan adanya perbedaan persepsi antara mahasiswa laki-laki dan mahasiswa perempuan sehingga hipotesis 2 dalam penelitian ini adalah: H2: Terdapat perbedaan persepsi antara laki-laki dan perempuan terhadap tujuan pendidikan etika profesi akuntansi.

\section{Metode}

\section{Instrumen Penelitian}

Metode penelitian ini merupakan penelitian kuantitatif. Data penelitian merupakan data primer yang diperoleh melalui kuesioner yang dibagikan kepada mahasiswa program studi akuntansi universitas terakreditasi baik di Kota Batam. Instrumen penelitian dalam penelitian ini adalah kuesioner 1 seberapa penting aspek-aspek umum etika bisnis, kuesioner 2 tujuan pendidikan etika profesi akuntansi dan kuesioner 3 perilaku mahasiswa berdasarkan jenis-jenis fraud. Penelitian ini adalah penelitian survei dengan menggunakan kuesioner dari penelitian Adkins dan Radtke (2004) yang diadopsi oleh Tormo (2016).

Metode penskalaan untuk isntrumen yang digunakan adalah skala likert (Likert scale) dengan mengukur respon subjek ke dalam 7 poin skala. Jawaban pada pertanyaan kuesioner 1 dan 2 diberikan pilihan rentang poin dari 1 sampai dengan 7. Poin satu menjelaskan bahwa tujuan etika yang terdapat di dalam kuesioner adalah tidak penting sampai dengan pilihan poin tujuh yang menunjukkan bahwa tujuan etika yang terdapat di dalam kuesioner adalah penting. Jawaban pada pertanyaan kuesioner 3 diberikan pilihan ya dan tidak. Kuesioner 1 dan 2 yang terdiri dari 11 pertanyaan akan dilakukan uji validitas dan reliabilitasnya untuk melihat apakah kuesioner dapat digunakan untuk penelitian ini. Sedangkan kuesioner 3 yang terdiri dari 13 pertanyaan digunakan untuk melihat persepsi mahasiswa berdasarkan jenis-jenis fraud sebagai tambahan.

\section{Teknik Penarikan Sampel dan Teknik Pengumpulan Data}

Teknik penarikan sampel yang digunakan adalah non probability sampling atau pengambilan sampel secara bukan random (acak). Salah satu teknik penarikan sampel non probability sampling yang digunakan adalah teknik penarikan sampel purposive sampling untuk mengambil sampel dari populasi berdasarkan suatu yaitu:

1. Mahasiswa program studi akuntansi tahun ajaran 2016/2017

2. Mahasiswa yang belajar di universitas terakreditasi baik di Kota Batam, memiliki mata kuliah etika dalam program studi akuntansi dengan status mahasiswa yang sudah mendapatkan mata kuliah etika dan mahasiswa yang belum mendapatkan mata kuliah etika.

Teknik pengumpulan data yaitu dengan melakukan survei dengan menggunakan kuesioner. Peneliti membagikan kuesioner langsung kepada para responden dengan teknik pengumpulan data yaitu survei langsung kepada responden yang menjadi sampel penelitian.

\section{Teknik Analisis Data}

Teknik analisis data yang dilakukan meliputi statistik deskriptif, uji validitas dan uji reliabilitas, uji normalitas dan uji mann withney $u$ test. Uji-uji tersebut dilakukan untuk menarik sebuah kesimpulan dari penelitian yang akan dilakukan. 


\section{Hasil Dan Pembahasan}

\section{Karakteristik Penelitian}

Kuesioner yang dibagikan sebanyak 580 kuesioner, kuesioner yang kembali sebanyak 566 kuesioner dan kuesioner yang bisa diolah sebanyak 499 kuesioner. Responden berdasarkan status mahasiswa yang dominan adalah mahasiswa yang sudah mendapatkan mata kuliah etika bisnis dengan persentase sebesar $67 \%$. Responden berdasarkan jenis kelamin yang dominan adalah mahasiswa perempuan dengan persentase sebesar $76 \%$. Responden berdasarkan semester yang dominan adalah mahasiswa semester 6 dengan persentase sebesar 36\%. Responden berdasarkan pekerjaan mahasiswa yang dominan adalah mahasiswa yang belum bekerja dengan persentase sebesar $51,7 \%$. Karakteritik responden dapat dilihat pada tabel 1 .

Tabel 1

\begin{tabular}{|c|c|c|}
\hline Keterangan & Frekuensi & Persentase \\
\hline \multicolumn{3}{|c|}{ Status } \\
\hline \begin{tabular}{llr}
\multicolumn{2}{l}{ Mahasiswa } & yang \\
sudah mendapatkan \\
mata kuliah etika \\
bisnis & & \\
\end{tabular} & 336 & $67 \%$ \\
\hline \begin{tabular}{l}
\multicolumn{2}{l}{ Mahasiswa } \\
belum mendapatkan \\
mata kuliah etika \\
bisnis
\end{tabular} & 163 & $33 \%$ \\
\hline \multicolumn{3}{|c|}{ Jenis Kelamin } \\
\hline Laki-laki & 121 & $24 \%$ \\
\hline Perempuan & 378 & $76 \%$ \\
\hline \multicolumn{3}{|c|}{ Semester } \\
\hline Semester 1 & 29 & $6 \%$ \\
\hline Semester 2 & 61 & $12 \%$ \\
\hline Semester 3 & 28 & $6 \%$ \\
\hline Semester 4 & 123 & $25 \%$ \\
\hline Semester 5 & 30 & $6 \%$ \\
\hline Semester 6 & 179 & $36 \%$ \\
\hline Semester 8 & 49 & $10 \%$ \\
\hline \multicolumn{3}{|c|}{ Pekerjaan } \\
\hline $\begin{array}{l}\text { Mahasiswa (Belum } \\
\text { bekerja) }\end{array}$ & 258 & $51,70 \%$ \\
\hline Karyawan Swasta & 77 & $15,40 \%$ \\
\hline Tax Officer & 1 & $0,20 \%$ \\
\hline Konsultan Pajak & 1 & $0,20 \%$ \\
\hline Accounting & 40 & $8 \%$ \\
\hline
\end{tabular}

\begin{tabular}{|c|c|c|}
\hline Finance & 3 & $0,60 \%$ \\
\hline Kasir Finance & 2 & $0,40 \%$ \\
\hline Acccounting Finance & 2 & $0,40 \%$ \\
\hline Auditor & 3 & $0,60 \%$ \\
\hline Magang Industri & 29 & $5,80 \%$ \\
\hline Wirausaha & 14 & $2,80 \%$ \\
\hline Marketing & 3 & $0,60 \%$ \\
\hline \begin{tabular}{|l} 
Staff \\
Receivable
\end{tabular} & 1 & $0,20 \%$ \\
\hline $\begin{array}{lr}\text { Staff Account } \\
\text { Receivable } \\
\text { Account Payable }\end{array}$ & 1 & $0,20 \%$ \\
\hline $\begin{array}{l}\text { Account Receivable } \\
\text { and Purchaser }\end{array}$ & 1 & $0,20 \%$ \\
\hline Admin Officer & 27 & $5,40 \%$ \\
\hline Admin Accounting & 1 & $0,20 \%$ \\
\hline Admin Kredit & 1 & $0,20 \%$ \\
\hline Staff Officer & 5 & $1 \%$ \\
\hline PNS & 4 & $0,80 \%$ \\
\hline Karyawan Honorer & 1 & $0,20 \%$ \\
\hline Manajer & 2 & $0,40 \%$ \\
\hline Guru & 3 & $0,60 \%$ \\
\hline Penerimaan Kas & 2 & $0,40 \%$ \\
\hline $\begin{array}{ll}\text { Customer } & \text { Services } \\
\text { Officer } & \\
\end{array}$ & 1 & $0,20 \%$ \\
\hline Sales & 4 & $0,80 \%$ \\
\hline Polisi & 2 & $0,40 \%$ \\
\hline Bank & 1 & $0,20 \%$ \\
\hline Instansi Pemerintah & 1 & $0,20 \%$ \\
\hline Frelance & 3 & $0,60 \%$ \\
\hline Notaris & 1 & $0,20 \%$ \\
\hline Recepcionist & 1 & $0,20 \%$ \\
\hline HRD & 3 & $0,60 \%$ \\
\hline Total & 499 & $100 \%$ \\
\hline
\end{tabular}

\section{Statistik Deskriptif}

Statistik deskriptif menunjukkan bahwa sebagian besar mahasiswa menganggap aspek-aspek umum etika bisnis dan tujuan pendidikan etika profesi akuntansi adalah penting, namun mahasiswa mengakui masih melakukan kecurangan. Kecurangan-kecurangan tersebut dikelompokkan oleh ACFE (Association of Certified Fraud Examiners) berdasaran jenis-jenis fraud internal. Pertama jenis fraud terhadap aset menunjukkan bahwa sebagian besar mahasiswa pernah melakukan penahanan cek pembayaran untuk vendor 
atau supplier dan pernah menggunakan fasilitas • perusahaan untuk kepentingan pribadi. Kedua jenis fraud terhadap laporan keuangan menunjukkan bahwa sebagian besar mahasiswa pernah mengakui suatu transaksi lebih besar atau lebih kecil dari yang seharusnya. Ketiga jenif fraud terhadap korupsi menunjukkan bahwa sebagian besar mahasiswa pernah membantu teman atau saudara untuk bekerja ditempat bekerja saat ini, menerima komisi dalam bentuk penerimaan suap atau kecurangan dan membocorkan rahasia perusahaan/lembaga (baik berupa data atau dokumen) apapun bentuknya.

Perilaku fraud dikelompokkan berdasarkan pekerjaan mahasiswa, semester mahasiswa, status mahasiswa dan jenis kelamin mahasiswa. Berdasarkan pekerjaan mahasiswa yang dominan dengan kategori fraud yang tinggi terdapat pada pekerjaan bagian perbankan. Berdasarkan semester mahasiswa yang dominan dengan kategori fraud yang sangat rendah terdapat pada mahasiswa semester 1 dan semester 3 . Berdasarkan status mahasiswa yang dominan dengan kategori fraud yang sangat rendah terdapat pada mahasiswa yang sudah mendapatkan mata kuliah etika bisnis. Berdasarrkan jenis kelamin yang dominan dengan kategori fraud yang sangat rendah terdapat pada mahasiswa laki-laki.

\section{Uji Validitas dan Uji Reliabilitas}

Hasil dari uji validitas data kuesioner aspek-aspek umum etika bisnis dan kuesioner tujuan pendidikan etika profesi akuntansi dengan 30 responden 11 item terlihat bahwa nilai $p$-value $>0,05$ yang menunjukkan bahwa tiap item adalah valid dan tingkat reliable yang diperoleh $\alpha>0,06$ yang menunjukkan bahwa tiap item adalah reliabel.

\section{Uji Normalitas}

Hasil dari uji normalitas kuesioner aspek-aspek umum etika bisnis dan kuesioner tujuan pendidikan etika profesi akuntansi menunjukkan bahwa nilai signifikan $<$ 0,05 yang menunjukkan bahwa data tidak berdistribusi normal.

\section{Pengujian Hipotesis}

Uji hipotesis yang digunakan adalah uji beda dengan menggunakan uji mann withney $u$ test sebagai alternatif data yang tidak berdistribusi normal.

\section{Terdapat Perbedaan Persepsi Antara Laki-Laki dan Perempuan Terhadap Aspek-Aspek Umum Etika Bisnis}

Hasil uji mann withney $u$ test dapat dilihat pada tabel 2. Pengambilan keputusan analisis dilihat dari angka probabilitas pada tabel Asymp sig (2-tailed). Angka signifikansi dibawah 0,05 yaitu 0,002 yang berarti bahwa terdapat perbedaan antara laki-laki dan perempuan dalam hal persepsi terhadap aspek-aspek umum etika bisnis. Maka dengan demikian H1 terdukung. Hasil rank uji mann withney u test pada tabel 3 menunjukkan rata-rata peringkat kelompok atau mean rank lebih dominan adalah mean rank perempuan 260,57 dibandingkan dengan mean rank laki-laki 216,98.

Tabel 2

\begin{tabular}{|l|c|}
\hline & $\begin{array}{c}\text { Aspek-Aspek } \\
\text { Umum Etika Bisnis }\end{array}$ \\
\hline Mann-Whitney U & 18874 \\
\hline Wilcoxon W & 26255 \\
\hline Z & $-3,12$ \\
\hline Asymp. Sig. (2-tailed) & 0,002 \\
\hline
\end{tabular}

Tabel 3

\begin{tabular}{|c|c|c|}
\hline \multicolumn{2}{|c|}{ Ranks } \\
\hline Jenis Kelamin & $\mathbf{N}$ & Mean Rank \\
\hline Laki-laki & 121 & 216,98 \\
\hline Perempuan & 378 & 260,57 \\
\hline N Total & 499 & \\
\hline
\end{tabular}

Hasil penelitian ini sama konsisten dengan penelitian Haspari (2013) yang menyimpulkan bahwa terdapat perbedaan yang signifikan tentang etika bisnis antara mahasiswa dan mahasiswi. Hasil penelitian ini juga sama konsisten dengan penelitian Stedham et.al (2007) yang menyimpulkan bahwa terdapat perbedaan yang signifikan dalam etika bisnis yaitu niat untuk berperilaku antara laki-laki dan perempuan dan terdapat perbedaan yang signifikan tentang perspektif keadilan dalam etika bisnis antara laki-laki dan perempuan. Hasil penelitian ini juga sama konsisten dengan penelitian Tormo (2016) yang menyimpulkan bahwa terdapat perbedaan persepsi antara mahasiswa laki-laki dan perempuan yaitu perempuan menganggap aspek umum etika bisnis lebih penting dari pada laki-laki. 
Perbedaan persepsi antara mahasiwa laki-laki dan perempuan bisa terjadi karena laki-laki dan perempuan memiliki peran sosial yang berbeda. Perbedaan peran tersebut menyebabkan laki-laki dan perempuan memiliki minat yang berbeda dan mengembangkan keterampilan yang berbeda (Eagly, 1987). Perbedaan tersebut juga sesuai dengan teori peran gender yaitu maskulin dan feminin yang dikemukakan oleh Bem (1981). Laki-laki memiliki sifat lebih berani dalam mengambil resiko, memiliki kemampuan analitis, membuat keputusan dengan mudah, individualistis, kompetitif dan ambisius. Perempuan memiliki sifat penurut atau patuh terhadap peraturan, pemalu, setia, sensitif terhadap kepentingan orang lain, memiliki pemahaman yang baik dan lemah lembut. Etika binis diperlukan untuk meningkatkan kualitas etika dalam proses pembuatan keputusan di lingkungan bisnis, sehingga keputusan yang diambil sesuai dengan kepentingan namun tidak melanggar etika dan tidak merugikan pihak lain.

- Terdapat Perbedaan Persepsi Antara Laki-Laki dan Perempuan Terhadap Tujuan Pendidikan Etika Profesi Akuntansi

Hasil uji mann withney $u$ test dapat dilihat pada tabel 4. Pengambilan keputusan analisis dilihat dari angka probabilitas pada tabel Asymp sig (2-tailed). Angka signifikansi dibawah 0,05 yaitu 0,016 yang berarti bahwa terdapat perbedaan antara laki-laki dan perempuan dalam hal persepsi terhadap tujuan pendidikan etika profesi akuntansi. Maka dengan demikian $\mathrm{H} 2$ terdukung. Hasil rank uji mann withney $u$ test pada tabel 5 menunjukkan rata-rata peringkat kelompok atau mean rank lebih dominan adalah mean rank perempuan 258,72 dibandingkan dengan mean rank laki-laki 222,77.

Tabel 4

\begin{tabular}{|l|c|}
\hline & $\begin{array}{c}\text { Tujuan } \\
\text { Pendidikan Etika } \\
\text { Profesi Akuntansi }\end{array}$ \\
\hline Mann-Whitney U & 19574,500 \\
\hline Wilcoxon W & 26955,500 \\
\hline Z & $-2,399$ \\
\hline Asymp. Sig. (2-tailed) &, 016 \\
\hline
\end{tabular}

Tabel 5

\begin{tabular}{|c|c|c|}
\hline \multicolumn{3}{|c|}{ Ranks } \\
\hline Jenis Kelamin & N & Mean Rank \\
\hline Laki-laki & 121 & 222,77 \\
\hline Perempuan & 378 & 258,72 \\
\hline N Total & 499 & \\
\hline
\end{tabular}

Hasil penelitian ini sama konsisten dengan penelitian Haspari (2013) yang menyimpulkan bahwa terdapat perbedaan yang signifikan tentang etika profesi akuntansi antara mahasiswa dan mahasiswi. Hasil penelitian ini juga sama konsisten dengan penelitian Tormo (2016) yang menyimpulkan bahwa terdapat perbedaan persepsi antara mahasiswa laki-laki dan perempuan yaitu perempuan menganggap tujuan pendidikan etika profesi akuntan lebih penting dari pada laki-laki.

Menurut teori peran sosial yang dikemukakan oleh Eagly (1987), perbedaan perilaku laki-laki dan perempuan terjadi karena dua jenis kelamin itu menempati peran sosial yang berbeda dalam kehidupan sehari-harinya. Perbedaan peran tersebut menyebabkan laki-laki dan perempuan memiliki minat yang berbeda dan mengembangkan keterampilan yang berbeda. Perbedaan tersebut juga sesuai dengan teori peran gender yaitu maskulin dan feminin yang dikemukakan oleh Bem (1981). Laki-laki memiliki sifat lebih berani dalam mengambil resiko, memiliki kemampuan analitis, membuat keputusan dengan mudah, individualistis, kompetitif dan ambisius. Perempuan memiliki sifat penurut atau patuh terhadap peraturan, pemalu, setia, sensitif terhadap kepentingan orang lain, memiliki pemahaman yang baik dan lemah lembut.

Tujuan pendidikan etika profesi akuntansi dalam mengembangkan suatu perasaan bertanggung jawab moral akan menjadikan mahasiswa sebagai seorang akuntan yang profesional tanpa melanggar etika dan tidak merugikan pihak lain. Pendidikan etika sangat bergantung pada dasar etika yang dimiliki oleh seseorang. Dasar etika dalam setiap individu berbedabeda tergantung dari latar belakang, budaya, pengalaman, standar moral dan sebagainya yang dimiliki. 


\section{Kesimpulan}

\section{Kesimpulan}

Hasil dari penelitian ini menunjukkan bahwa:

a. Terdapat perbedaan persepsi antara mahasiswa laki-laki dan perempuan terhadap aspek-aspek umum etika bisnis. Mahasiswa perempuan menganggap aspek-aspek umum etika bisnis lebih penting dibandingkan dengan mahasiswa laki-laki.

b. Terdapat perbedaan persepsi antara mahasiswa laki-laki dan perempuan terhadap tujuan pendidikan etika profesi akuntansi. Mahasiswa perempuan menganggap tujuan pendidikan etika profesi akuntansi lebih penting dibandingkan dengan mahasiswa lakilaki.

Perbedaan perilaku laki-laki dan perempuan terjadi karena dua jenis kelamin itu menempati peran sosial yang berbeda dalam kehidupan sehari-harinya seperti pekerjaan yang mereka miliki saat ini. Perbedaan perilaku laki-laki dan perempuan juga terjadi karena dua jenis kelamin tersebut memiliki sifat dan karakter yang berbeda. Laki-laki memiliki sifat maskulin yaitu mandiri, membela keyakinan sendiri/mempertahankan kepercayaan diri sendiri, independen, atletik, tegas, kepribadian yang kuat, kuat, analitis, kemampuan kepemimpinan, bersedia untuk mengambil resiko, membuat keputusan dengan mudah, mencukupi diri/mandiri, dominan/menonjol, maskulin, harus berdiri tegak, agresif, bertindak sebagai pemimpin, individualistis, kompetetif dan ambisius. Perempuan memiliki sifat feminin seperti penurut, ceria, pemalu, penuh kasih sayang, disanjung, setia, feminin, simpatik, sensitif terhadap kebutuhan orang lain, pemahaman, berbelas kasih, bersemangat untuk menenangkan perasaan terluka, lembut dalam berbicara, hangat, lembut, mudah tertipu, kekanakkanakan, tidak menggunakan bahasa keras, menyukai anak-anak dan lemah lembut.

Sebagian besar mahasiswa menganggap aspek-aspek umum etika bisnis dan tujuan pendidikan etika profesi akuntansi adalah penting, namun sebagian besar mahasiswa mengakui pernah melakukan kecurangan. Kecurangan tersebut diantaranya melakukan penahanan cek pembayaran untuk vendor atau supplier, menggunakan fasilitas perusahaan untuk kepentingan pribadi, mengakui suatu transaksi lebih besar atau lebih kecil dari yang seharusnya, membantu teman atau saudara untuk bekerja di tempat bekerja saat ini, menerima komisi dalam bentuk penerimaan suap atau kecurangan dan membocorkan rahasia perusahaan/lembaga (baik berupa data atau dokumen) apapun bentuknya. Perilaku fraud pada mahasiswa yang bekerja di bank, mahasiswa semester 1 dan semester 3, mahasiswa yang telah mendapatkan mata kuliah etika dan mahasiswa laki-laki memiliki kategori yang rendah tetapi dominan di dalam kelompoknya.

\section{Keterbatasan}

Penelitian ini memiliki beberapa keterbatasan baik dari jumlah sampel maupun faktor-faktor yang lain yaitu:

1. Sampel yang digunakan dalam penelitian ini tidak terlalu luas yaitu hanya mahasiswa program studi akuntansi kelas malam yang belum mendapatkan gelar.

2. Survei pada penelitian ini hanya dilakukan pada universitas terakreditasi baik di Kota Batam saja yaitu Politeknik Negeri Batam, Universitas Internasional Batam, Universitas Batam dan Universitas Riau Kepulauan.

3. Penelitian ini hanya menggunakan 1 variabel dalam mengukur perbedaan yaitu jenis kelamin.

4. Kurang tercipta hubungan yang baik antara peneliti dengan responden karena survei yang dilakukan sebagian besar tidak secara langsung bertatap muka, sehingga peneliti kurang mendapatkan kepercayaan responden dan responden tidak bisa bertanya secara langsung kepada peneliti apabila ada kuesioner yang kurang dipahami.

5. Jawaban atas kuesioner tentang fraud kurang efektif karena tidak semua mahasiswa kelas malam bekerja sebagai accounting.

\section{Implikasi dan Saran}

Hasil dari penelitian ini menunjukkan ada perbedaan persepsi antara mahasiswa laki-laki dan perempuan. Sebagian besar mahasiswa menganggap aspek-aspek umum etika bisnis dan tujuan pendidikan etika profesi akuntansi adalah penting, namun mahasiswa mengakui masih melakukan kecurangan-kecurangan. Hal ini menunjukkan bahwa pendidikan etika sangat penting 
untuk bekal mahasiswa dan harus lebih dimaksimalkan dalam kurikulumnya. Pada dasarnya mahasiswa telah mendapatkan pelajaran tentang etika di dalam kehidupan sehari-hari, namun untuk lebih mempersiapkan pelaku bisnis yang baik di masa yang akan datang maka pemberian ilmu lebih mendalam seputar etika bisnis dan juga pembelajaran tentang etika adalah perlu. Mahasiswa tidak hanya memahami teori saja namun dapat menjalankannya dalam kehidupan sehari-hari dan dapat mengurangi kecurangan walau hanya sebagian kecil, karena suatu hal yang baik dimulai dari hal kecil. Hal ini perlu menjadi pertimbangan bagi universitas sehingga untuk kedepannya masalah tentang etika bisnis yang masih ada di Indonesia dapat berkurang sedikit demi sedikit yang dimulai dari kesadaran diri sendiri.

Saran untuk penelitian selanjutnya adalah sampel yang diteliti di perluas seperti menggunakan sampel mahasiswa program studi akuntansi yang ada di Kota Batam dan bisa menambahkan faktor eksternal yang menentukan perilaku kecurangan. Melakukan penelitian seputar kecurangan-kecurangan yang telah terjadi seperti penahanan cek pembayaran untuk vendor atau supplier, menggunakan fasilitas perusahaan untuk kepentingan pribadi, mengakui suatu transaksi lebih besar atau lebih kecil dari yang seharusnya, membantu teman atau saudara untuk bekerja ditempat bekerja saat ini, menerima komisi dalam bentuk penerimaan suap atau kecurangan dan membocorkan rahasia perusahaan (baik berupa data atau dokumen) apapun bentuknya.

\section{Daftar Pustaka}

ACFE. (2017). What Is Fraud. Diambil kembali dari www.acfe.com/fraud-101.aspx

Adkins, N., \& Radtke, R. R. (2004). Students' and Faculty Members' Perceptions of the Importance of Business Ethics and Accounting Ethics Education: Is There an Expectations Gap? Business Ethics, 51(3), 279-300.

Ajzen, I. (1985). From Intentions to Actions: A Theory Planned Behavior. Srpinger Berlin Heidelberg.

Anastasyah, D. (2016). Perbedaan Persepsi Tentang
Etika Bisnis Pada Mahasiswa yang Belum dan Sudah Mempelajari Mata Kuliah Etika Bisnis Pada Prodi Akuntansi di Perguruan Tinggi Kota Batam. Politeknik Negeri Batam.

Ardana, Agus, S., \& Cenik. (2009). Etika Bisnis dan Profesi. Jakarta: Salemba Empat.

Arikunto, S. (1995). Manajemen Penelitian. Jakarta: Rineka Cipta.

Biyantari, N. (2017). Etika Profesi Akuntansi. Diambil kembali dari https://www.academia.edu/11951930/Etika_Prof esi_Akuntansi

Black, E. L., Burton, F. G., Chavez, S. R., Hardy, S., Radebaugh, L. H., Riccio, E. H., et al. (2010, December). Does Education and Training in Ethics Affect the Ethical Awareness of Practicing Accountants. 1-75.

Callahan, D. (1980). Ethics Teaching in High Education. New York: Springer.

Eagly, A. H., \& Steffen, V. J. (1984). Gender Stereotypes Stem Form the Distribution of Women and Men Into Social Roles. Journal of Personality and Social Pyschology, 46(4), 735 754.

Fakih. (2001). Analisis Gender dan Transformasi Sosial. Yogyakarta: Pustaka Pelajar.

Fishbein, M, \& Ajzen, I. (1975). Belief, Attitude, Intention, and Behavior: An Introduction to Theory and Research.

Ghozali, I. (2011). Aplikasi Analisis Multivariate dengan Program IBM SPSS 20 (Edisi 6 ed.). (P. P. Harto, Penyunt.) Semarang: Badan Penerbit Universitas Diponegoro.

Gozali, I. (2011). Aplikasi Analisis Multivariate dengan Program IBM SPSS 20. Dalam Harto

(Penyunt.). Semarang: Badan Penerbit Universitas Diponegoro.

Griffin, R., \& J. Ebert, R. (2006). Bisnis. Jakarta: Erlangga.

Hartono, J. (2015). Metodologi Penelitian Bisnis Salah Kaprah dan Pengalaman-Pengalaman (6 ed.). Yogyakarta: BPEE-Yogyakarta.

Haspari, N. P. (2013). Persepsi Mahasiswa dan Mahasiswi Terhadap Etika Bisnis dan Etika 
Profesi. Surakarta: Universitas Muhammadiyah Surakarta.

Hendry. (2016). Populasi dan Sampel. Diambil kembali dari https://teorionline.wordpress.com/tag/sampelpopulasi-penelitian-teknik-sampling/

Indonesia, P. R. (1989). Undang-Undang Republik Indonesia Nomor 2 Tahun 1989 Tentang Sistem Pendidikan Nasional. Diambil kembali dari related:www.hukumonline.com/pusatdata/downl oadfile/lt4c3d44a89102b/parent/17215

Juliarta, G., Herawati, N. T., \& Sulindawati, N. G. (2015). Persepsi Mahasiswa Jurusan Akuntansi dan Akuntan Publik Terhadap Etika Bisnis dan Etika Profesi Akuntan. JIMAT, 3(1).

KBBI. (2012). Persepsi. Diambil kembali dari http://kbbi.web.id/persepsi

KBBI. (2015). Arti Kata "Etika" Menurut KBBI. Diambil kembali dari http://kbbi.co.id/artikata/etika

Keraf, A. S. (1998). Etika Bisnis, Tuntutan dan Relevansinya. Yogyakarta: Kanisius.

KeuanganLSM. (2015, Maret 25). Jenis-Jenis Fraud. Diambil kembali dari keuanganlsm.com/jenisjenis-fraud/

Monto, M. A. (1993). An Exercise in Gender: The BEM Sex Role Inventory in the Classroom. Clinical Sociology Review, 159-174.

Murtanto, \& Marini. (2003, Oktober). Persepsi Akuntan Pria dan Akuntan Wanita Serta Mahasiswa dan Mahasiswi AKuntansi Terhadap Etika Bisnis dan Etika Profesi AKuntan. 790805.

Nauly, M. (2002). Konflik Peran Gender pada Pria : Reori dan Pendekatan Empirik. Fakultas Kedokteran Program Studi Psikologi Universitas Sumatera Utara.

Pamelia, A. (2014). Pengaruh Pemahaman Kode Etik Profesi Akuntan Terhadap Perilaku Etis Pada

Mahasiswa AKuntansi Universitas Negeri Yogyakarta. Universitas Negeri Yogyakarta.

Poniman. (2009). Persepsi Akuntan Pria dan Akuntan Wanita Terhadap Etika Bisnis dan Etika Profesi Akuntan. JAI, 5(1), 105-117.

Pradipta, R. A. (2012, Juli). Analisis Persepsi
Mahasiswa dan Dosen Tentang Pendidikan Etika dan Profesi Akuntan. Depok: Universitas Indonesia.

Rinjani, K. (2004). Etika Bisnis dan Implementasinya. Jakarta: PT Gramedia Pustaka Utama.

Robbins, \& S. P. (1996). Perilaku Organisasi: Konsep, Kontroversi, Aplikasi. Jakarta: PT. Prenhalindo.

Rustiana. (2006). Persepsi Etika Mahasiswa Akuntansi dan Auditor Dalam Situasi Dilema Etis Akuntansi. Kinerja, 10(2), 116-128.

Satyarini, M., Wulandari, R., Wuri, T., Pertama, P., \& Latifah, M. (2015, Mei). Gender. Diambil kembali dari http://princesscounseling.blogspot.co.id/2015/05 /diskriminasi-gender.html

Slameto. (2010). Belajar dan Faktor-Faktor yang Mempengaruhinya. Jakarta: Rineka Cipta.

Stedham, Y., Yamamura, J., \& Beekun, R. (2007). Gender Diffeneces in Business Ethics: Justice and Relattivist Perspectives. Business Ethics : A European review, 163-174.

Sugiyono, D. (2003). Statistika untuk Penelitian. (S. Apri Nuryanto, Penyunt.) Bandung: CV Alfabeta. 